\title{
Electrochemical Oxidation of Different Therapeutic Classes of Pharmaceuticals Using Graphite-PVC Composite Electrode
}

\author{
Zainab H. Mussa, ${ }^{1}$ Fouad F. Al-Qaim, ${ }^{2, \star}$ Zahraa H. Alqaim $^{3}$ and Jalifah Latip ${ }^{4}$ \\ ${ }^{1}$ Faculty of Pharmacy, University of Al-Ameed, Karbala, Iraq \\ ${ }^{2}$ Department of Chemistry, Faculty of Science for Women, University of Babylon, PO Box 4, Hilla, Iraq \\ ${ }^{3}$ Medical laboratories Technique Department, Al-Mustaqbal University College, Iraq \\ ${ }^{4}$ School of Chemical Sciences and Food Technology, Faculty of Science and Technology, \\ Universiti Kebangsaan Malaysia, Selangor, Malaysia \\ *Corresponding author: E-mail: fouadalkaim@yahoo.com
}

Received: 02-27-2021

\begin{abstract}
This study reports electrochemical treatment of different therapeutic classes of pharmaceuticals (caffeine, prazosin, enalapril, carbamazepine, nifedipine, levonorgestrel, and simvastatin) in a mixture. The electrochemical process was investigated using graphite-PVC anode at different applied voltages $(3,5$, and $12 \mathrm{~V})$, initial concentrations of studied pharmaceuticals in aqueous solution ( 5 and $10 \mathrm{mg} / \mathrm{L}$ ), and concentrations of sodium chloride $(1$ and $2 \mathrm{~g} / \mathrm{L}$ ). The $\%$ removal of pharmaceuticals increased with the applied voltage, and was found higher than $98 \%$ after $50 \mathrm{~min}$ of electrolysis at $5 \mathrm{~V}$. Energy consumption ranged between 0.760 and $3.300 \mathrm{Wh} / \mathrm{mg}$ using $12 \mathrm{~V}$ being the highest value compared to 3 and 5 $V$. The formation of chlorinated by-products from four selected pharmaceuticals, simvastatin $\left(\mathrm{C}_{11} \mathrm{H}_{13} \mathrm{Cl}_{3} \mathrm{O}_{5}\right.$, and $\mathrm{C}_{10} \mathrm{H}_{12}$ $\left.\mathrm{Cl}_{4} \mathrm{O}_{3}\right)$, prazosin $\left(\mathrm{C}_{13} \mathrm{H}_{12} \mathrm{Cl}_{3} \mathrm{~N}_{5} \mathrm{O}_{3}\right.$ and $\left.\mathrm{C}_{10} \mathrm{H}_{11} \mathrm{Cl}_{4} \mathrm{~N}_{2} \mathrm{O}_{2}\right)$, carbamazepine and caffeine $\left(\mathrm{C}_{15} \mathrm{H}_{11} \mathrm{~N}_{2} \mathrm{O}_{2} \mathrm{Cl}\right.$ and $\left.\mathrm{C}_{8} \mathrm{H}_{9} \mathrm{~N}_{4} \mathrm{O}_{2} \mathrm{Cl}\right)$ was identified and elucidated using liquid chromatography-time of flight mass spectrometry (LC-TOF/MS).
\end{abstract}

Keywords: Pharmaceuticals; indirect electrochemical oxidation process; graphite-PVC anode; solid phase extraction; LC-TOF/MS; energy consumption

\section{Introduction}

Pharmaceuticals are defined as organic compounds used for the treatment of disease. They are present in prescription medicines, over-the-counter therapeutic drugs, and veterinary drugs. Different therapeutic classes of pharmaceuticals such as caffeine, prazosin, enalapril, carbamazepine, nifedipine, levonorgestrel, and simvastatin are categorized and prescribed for different treatments.

Caffeine is one of the most widely used drugs for the nervous system. It is considered a non-prescribed drug as it is available naturally in tea and coffee. Caffeine is used as a central nervous system (CNS) stimulant, mild diuretic, and respiratory stimulant (in neonates with apnea of prematurity). Caffeine is used to treat migraines and other headache types. ${ }^{1}$ Prazosin is one of the antihypertensive compounds. It is used for the treatment of hypertension, symptomatic benign prostatic hyperplasia, and severe congestive heart failure. ${ }^{1}$ Enalapril is an example of renin-angiotensin system inhibitor that is used for the treatment of essential or renovascular hypertension and symptomatic congestive heart failure. ${ }^{1}$ Carbamazepine is one of the most widely used antiepileptic drugs to treat partial seizures, tonic-clonic seizures, and the pain of neurologic origin such as trigeminal neuralgia. ${ }^{1}$ Nifedipine is one of the calcium channel blockers (CCBs) class that is used to treat chronic stable angina, hypertension, and Raynaud's phenomenon. ${ }^{1}$ Levonorgestrel is a progestin or a synthetic form of the naturally occurring female sex hormone, progesterone. Levonorgestrel is used for the treatment of menopausal and postmenopausal disorders alone or in combination with other hormones as an oral contraceptive. ${ }^{1}$ Simvastatin, the methylated form of lovastatin, is a lipid-modifying agent that inhibits HMG-CoA reductase 
(3-hydroxy-3-methyl-glutaryl-CoA reductase). Simvastatin is used in the treatment of primary hypercholesterolemia. It is effective in reducing total and LDL-cholesterol as well as plasma triglycerides and apolipoprotein B. ${ }^{1}$

Pharmaceutical compounds were detected in the surface water situated near the sewage water treatment plants (STP). ${ }^{2}$ The detection of pharmaceuticals in the aquatic environment at trace levels ranging from nanograms to micrograms per litre has been widely discussed and published in previous studies., ${ }^{3,5}$ In Malaysia, the studied pharmaceuticals have been analysed and frequently detected in water samples such as influent and effluent of sewage treatment plants, hospitals, and surface water. ${ }^{6,7,8,9,10}$ In Malaysia, the main sewage treatment plant applies a biological treatment process, which is unable to accomplish complete degradation of some pharmaceuticals. However, caffeine was found in the effluent sewage treatment plants up to $1464 \mathrm{ng} / \mathrm{L}$, while prazosin and other pharmaceuticals were detected between 16 and $77 \mathrm{ng} / \mathrm{L}$. Nifedipine was not detected anymore because it is light-sensitive, which causes rapid photodegradation. ${ }^{6}$ Biological treatment methods are extensively used for the removal of pharmaceuticals from wastewater. It was observed that the option of biological treatment may not be suitable because microbial growth could be inhibited in the presence of chloride. ${ }^{11}$ Advanced oxidation process (AOP) was attempted to remove the pharmaceutical compounds but their degradation was observed to be only partial. ${ }^{12}$ Thus, looking for an alternative treatment process is necessary to remove the pharmaceuticals from water bodies.

The electrochemical oxidation process for wastewater treatment has been widely applied due to its environmental friendliness, amenability to automation, and effectiveness to process wide variety of organic pollutants. ${ }^{13}$ The removal of a wide spectrum of pharmaceuticals from aqueous solution using graphite-PVC electrode was reported in our previous studies. ${ }^{14}$ The electrochemical oxidation process could be classified into indirect and direct electrochemical processes. When the organic pollutants are degraded by anodic electrodes after adsorption of these pollutants on the anode, this type is called a direct process. In contrast, an indirect electrochemical process is the elimination of compounds in bulk solution, which is accompanied by strong and active oxidizing agents such as hypochlorite/chlorine. ${ }^{15}$ The mechanism of formation of hypochlorite, chloride, and chlorine could be illustrated by these equations:

$$
\begin{aligned}
& 2 \mathrm{Cl}^{-} \rightarrow \mathrm{Cl}_{2}+2 \mathrm{e}^{-} \\
& \mathrm{Cl}_{2}+\mathrm{H}_{2} \mathrm{O} \rightarrow \mathrm{H}^{+}+\mathrm{Cl}^{-}+\mathrm{HOCl} \\
& \mathrm{HOCl} \leftrightarrow \mathrm{H}^{+}+\mathrm{ClO}^{-}
\end{aligned}
$$

Combining ultrasonic and electrochemical oxidation as advanced oxidation process using graphite as a cathode has been used for the degradation of malachite green wastewater. It was observed that the highest degradation of malachite green obtained was $94.24 \%$ when the voltage was $20 \mathrm{~V}$, ultrasonic power was $300 \mathrm{~W}$, and electrolyte solution was $15.0 \mathrm{~g} / \mathrm{L} \mathrm{Na}_{2} \mathrm{SO}_{4}{ }^{16}$ Treatment of domestic wastewater has been given a big attention to reduce its impact on the aquatic environment. Using iron(III) doped titanium dioxide-coated graphite electrode exhibited good potential application on the purification of domestic wastewater. ${ }^{17}$ Graphite electrode has been used as anode for electrochemical degradation of raw water and digested water. It was observed that the\% removal in terms of chemical oxygen demand (COD) was $37 \%$ and $25 \%$ for raw water and digested water, respectively. ${ }^{18}$

The electrochemical oxidation process has been applied for the degradation of real biotreated petrochemical wastewater. However, different parameters have been studied such as current density, $\mathrm{pH}$ value, agitation rate, and anode materials on their influence on the\% removal of COD of real biotreated petrochemical wastewater. It was observed that higher oxidation occurred at the current density of $10 \mathrm{~mA} / \mathrm{cm}^{2}$, a $\mathrm{pH}$ value of 3 , and an agitation rate of $400 \mathrm{rpm} .{ }^{19}$ The application of indirect electrochemical process reported that diclofenac, simvastatin, and their by-products were completely removed after $140 \mathrm{~min}$ using graphite-PVC composite anode. ${ }^{20,21}$ The COD of synthetic textile effluent was removed $\geq 75 \%$ using graphite rod anode for $45 \mathrm{~min} .{ }^{22}$ It was observed that the electrochemical oxidation process has achieved more than $90 \%$ removal of COD, BOD, and colour of textile dye using $\mathrm{Ag} / \mathrm{C}$ composite anode after $100 \mathrm{~min} .{ }^{23}$ Indirect electrochemical treatment of landfill leachate showed $87 \%$ removal of COD using graphite-PVC anode by operating at $15 \mathrm{~V}$ applied voltage for $105 \mathrm{~min}$ of electrolysis. ${ }^{24}$ However, the electrochemical oxidation process was not applied yet for the removal of different therapeutic classes of pharmaceuticals mixture in one batch.

This study aims to determine the effectiveness of an electrochemical process using graphite-PVC as anode for the degradation of different therapeutic classes of pharmaceuticals in one mixture. The pharmaceuticals were further identified for the formation of their chlorinated by-products during the electrochemical treatment process using LC-TOF/MS.

\section{Experimental}

\section{1. Materials and Methods}

Pure standards ( $\geq 98 \%$ ) of nifedipine (NFD) (CAS no. 21829- 25-4), enalapril maleate (ENL) (CAS no. 7609516-4), prazosin (PRZ) (CAS no. 19237-84-4), caffeine (CAF) (CAS no. 58-08-2), levonorgestrel (LNG) (CAS no. 797-63-7), carbamazepine (CBZ) (CAS no. 298-46-4), simvastatin (SMV) (CAS no. 79902-63-9) were purchased 
<smiles>COc1cc2nc(N3CCN(C(=O)c4ccco4)CC3)nc(N)c2cc1OC</smiles>

Caffeine<smiles>C#CC1(O)CCC2C3CCC4=CC(=O)CCC4C3CCC21CC</smiles>

Levonorgestrel

Prazosin

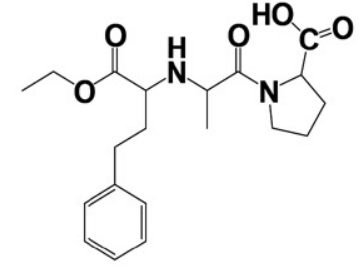

Enalapril<smiles>NC(=O)N1c2ccccc2C=Cc2ccccc21</smiles>

Carbamazepine<smiles>COC(=O)C1=C(C)NC(C)C2C(OC)CC3C=CC(O3)C12</smiles>

Nifedipine

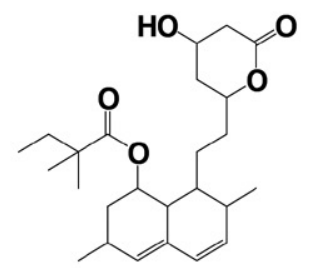

Simvastatin

Figure 1. Chemical structures of seven pharmaceutical compounds

from Sigma-Aldrich (St. Louis, MO). Deionized water (DIW) was supplied by EASYPure RODI (Thermo Fisher Scientific, Waltham, MA). HPLC-grade methanol $(\mathrm{MeOH})$, acetonitrile $(\mathrm{ACN})$, acetone, and formic acid (FA) were supplied by Merck (Darmstadt, Germany). The chemical structure of all studied pharmaceuticals is presented in Figure 1.

The consumption profile of the studied pharmaceutical compounds in a particular country affects the profile of compounds found in wastewater and surface water. In Malaysia, Ministry of health publishes annually statistical report on drug consumption. ${ }^{25}$ Table 1 presents the defined daily doses (DDD) of a drug per thousand inhabitants of the studied pharmaceuticals as a top 50 consumed pharmaceutical compounds over the years 2011-2014 in Malaysia. The DDD values are based on Anatomical Therapeutic Chemical (ATC) classification system by World Health Organization (WHO). ${ }^{26}$ The annual consumption $(\mathrm{kg} / \mathrm{y})$ of the pharmaceuticals can be calculated using the following formula:

$$
\begin{aligned}
\text { Consumption }(\mathrm{kg} / \mathrm{y})= & \mathrm{DDD}(\mathrm{g}) \times \frac{\mathrm{DDD}}{1000 \mathrm{inh}} \times \\
& \times \frac{\text { Population }}{1000000} \times 366
\end{aligned}
$$

\section{2. Standard Preparation and Graphite-PVC Electrochemical Setup}

A $1000 \mathrm{mg} / \mathrm{L}$ solutions of the standards were prepared individually using methanol as a solvent and stored at -18 . A mixture of solutions was prepared in water after an appropriate dilution of the individual standard. The conductivity of solutions was controlled by adding different amounts of $\mathrm{NaCl}$ (Merck, Germany). All experiments were conducted using a Pyrex glass vessel $(100 \mathrm{~mL})$. The

\begin{tabular}{|c|c|c|c|c|c|c|}
\hline \multirow{2}{*}{ Compound } & \multirow{2}{*}{ Classification } & \multirow{2}{*}{$\operatorname{DDD}(\mathbf{m g})^{\mathrm{a}}$} & \multicolumn{4}{|c|}{ Consumption $(\mathrm{kg} / \mathrm{y})$} \\
\hline & & & 2011 & 2012 & 2013 & 2014 \\
\hline Caffeine $^{b}$ & Stimulant & $400(\mathrm{O}, \mathrm{P})$ & - & - & - & - \\
\hline Enalapril & Renin-angiotensin system inhibitors & $10(\mathrm{O}, \mathrm{P})$ & 597 & 616 & 564 & 667 \\
\hline Carbamazepine $^{c}$ & Anti-epileptics & $1000(\mathrm{O}, \mathrm{R})$ & - & - & - & - \\
\hline Nifedipine & Calcium channel blockers & $30(\mathrm{O}, \mathrm{P})$ & 2004 & 1650 & 1235 & 998 \\
\hline \multirow{2}{*}{\multicolumn{2}{|c|}{$\begin{array}{l}\text { Population } \\
\text { (10 } 10^{7} \text { inhabitants) }\end{array}$}} & & & & & \\
\hline & & & 2.9062 & 2.9510 & 2.9915 & 3.0261 \\
\hline
\end{tabular}

Table 1. Defined daily doses and the consumption of the selected pharmaceuticals in Malaysia 2011-2014

${ }^{\mathrm{a}}$ WHO (2018), ${ }^{\mathrm{b}}$ over-the-counter compounds, ${ }^{\mathrm{c}}$ compound not listed as top 50 consumed pharmaceuticals in Malaysia (2011-2014).

$\mathrm{O}=$ Oral, $\mathrm{P}=$ Parenteral, $\mathrm{R}=$ Rectanal, NA: not available. 


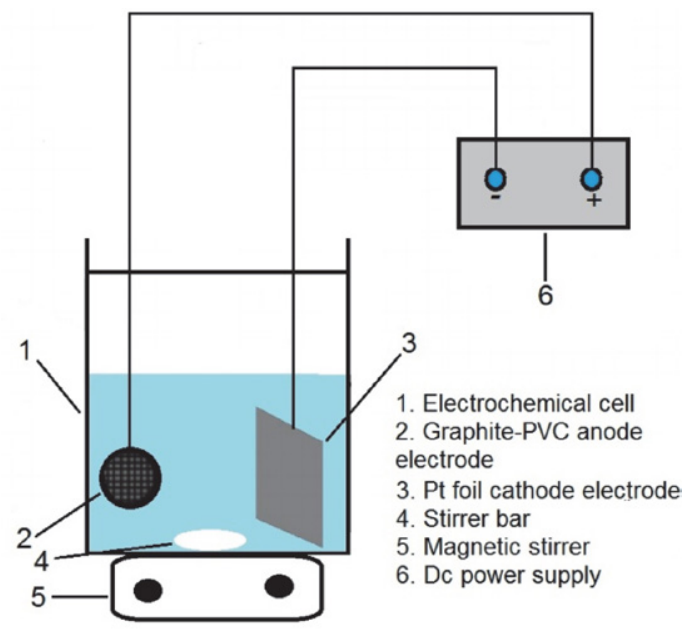

Figure 2. Electrochemical cell set up

Pyrex glass electrochemical cell (reactor) was placed on a magnetic stirring block to keep its contents well mixed during the experiment as shown in Figure 2.

Pt metal foil and graphite-PVC as cathode and anode, respectively, were prepared according to the previously reported procedure. ${ }^{24}$ Graphite-PVC pellet was used as anode and prepared from the graphite powder. ${ }^{20}$ The distance between two electrodes in the electrochemical cell was $2.5 \mathrm{~cm}$ in all experiments. The electrodes were connected to a DC power supply (CPX200 DUAL, 35V 10A PSU).

\section{3. Electrochemical Treatment Procedure}

Aqueous solution of 5 and $10 \mathrm{mg} / \mathrm{L}$ of the seven compounds were prepared in deionized water. All solutions were treated electrochemically at applied voltages of $3 \mathrm{~V}, 5 \mathrm{~V}$, and $12 \mathrm{~V}$. The\% removal was calculated according to the equation (5). Comparative electrochemical experiments of $100 \mathrm{~mL}$ mixture solutions of caffeine, prazosin, enelapril, carbamazepine, levonorgestrel, nifedipine and simvastatin in deionized water were provided. The intervals were $0,10,20,30,40$, and $50 \mathrm{~min}$. The monitoring of the chlorinated by-products was performed after solid phase extraction for caffeine, prazosin, simvastatin and carbamazepine only at fixed conditions: $100 \mathrm{~mL}$ of solution, $0.5 \mathrm{mg} / \mathrm{L}$ of compound, $5 \mathrm{~V}$ of applied voltage and $0.2 \mathrm{~g} \mathrm{NaCl}$ as supporting electrolyte.

$$
R \%=\frac{A_{0}-A_{t}}{A_{0}} \times 100 \%
$$

Where $R \%$ is the percentage\% removal of parent compound; $A_{0}$ is the initial peak area of parent compound; $A_{\mathrm{t}}$ is the residual peak area after time $(t)$.

\section{4. Solid Phase Extraction Method}

It is well known that by-products could be formed after the treatment of pharmaceuticals individually. An Oasis HLB (3 cc, $60 \mathrm{mg}$ ) cartridge from Waters (Milford, MA) was used for the purpose of SPE. The solid phase extraction method was conducted according to the previous study as follows: all experiments were subjected to a 10-sample GAST SPE vacuum manifold DOA-P504-BN (Büchi Labortechnik AG, Flawil, Switzerland), treated samples were loaded at a flow rate of $3 \mathrm{~mL} / \mathrm{min}$ under vacuum conditions then the by-products were eluted out of sorbent using $5 \mathrm{~mL}$ of methanol. ${ }^{27}$ Dry extracts were reconstituted with $500 \mu \mathrm{L}$ of solvent and filtered using 0.2 $\mu \mathrm{m}$ Nylon syringe filters. A $30 \mu \mathrm{L}$ of the extract was automatically injected into the LC-ESI-TOF/MS system for analysis.

\subsection{Chemical Analysis}

All pharmaceuticals and their by-products were separated on a Gemini $5 \mu \mathrm{m}$ NX $110 \AA$ C18 column $2 \mathrm{~mm} \times$ $150 \mathrm{~mm}$ (Phenomenex, Torrance, CA) using a Dionex Ul-

Table 2. Chromatographic separation of selected pharmaceuticals and their by-products for both PI and NI ESI-TOF/MS modes

\section{Positive ion (only selected pharmaceuticals)}

Mobile phase

Flow rate

Injection volume

Gradient program

$$
\begin{gathered}
\text { Time (min) } \\
\text { B\% }
\end{gathered}
$$

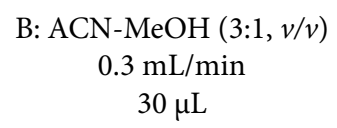

\begin{tabular}{|c|c|c|c|c|c|c|}
\hline \multicolumn{7}{|c|}{ Negative ion (by-products) } \\
\hline Mobile phase & & \multirow{2}{*}{\multicolumn{5}{|c|}{$\begin{array}{c}\text { A: } 0.1 \% \text { FA in DIW } \\
\text { B: ACN-MeOH }(2: 3, v / v)\end{array}$}} \\
\hline & & & & & & \\
\hline Flow rate & & \multicolumn{5}{|c|}{$0.3 \mathrm{~mL} / \mathrm{min}$} \\
\hline Injection volume & & & & $30 \mu \mathrm{L}$ & & \\
\hline \multirow[t]{2}{*}{ Gradient program } & Time (min) & 0 & 5 & 10 & 10.1 & 15.1 \\
\hline & $\mathrm{B} \%$ & $5 \%$ & $95 \%$ & $95 \%$ & $5 \%$ & $5 \%$ \\
\hline
\end{tabular}

$\begin{array}{cccc}6 & 11 & 11.1 & 16.1 \\ 97 \% & 97 \% & 5 \% & 5 \%\end{array}$

A: $0.1 \%$ FA in DIW 
timate 3000/LC 09115047 (Thermo Fisher Scientific, Waltham, MA) system equipped with a vacuum degasser, a quaternary pump, and an auto-sampler. The studied pharmaceuticals were analysed by TOF/MS in positive ESI ionization mode while the by-products were analysed in negative ESI ionization mode. The mobile phase and elution program are presented in Table 2.

\section{Results and Discussion}

According to our previous work, the electrochemical process was influenced by the initial concentration of the pharmaceuticals, $\mathrm{NaCl}$ amount, and applied voltage during the treatment of organic pollutants. Mainly, the oxidation of pollutants could take place by a strong oxidizing agent, which was chlorine/hypochlorite. ${ }^{27,28}$

\section{1. Effect of Initial Concentration}

A mixture of the studied pharmaceuticals solution with two different initial concentrations of 5 and $10 \mathrm{mg} / \mathrm{L}$, was treated by indirect electrochemical oxidation process using graphite-PVC as the anode at a fixed applied voltage of $5 \mathrm{~V}$ and $2 \mathrm{~g} / \mathrm{L} \mathrm{NaCl}$. The\% removal was plotted against electrochemical treatment time for both initial concentrations as shown in Figure 3a. Degradation of pharmaceuticals was achieved in all cases; however, it is evident that faster elimination occurred at lower initial concentration. At $5 \mathrm{mg} / \mathrm{L}$ and $5 \mathrm{~V}$, three pharmaceuticals were eliminated in a reaction time of $50 \mathrm{~min}$, but at $10 \mathrm{mg} / \mathrm{L}$ and $5 \mathrm{~V}$, the complete degradation may require a longer time. As the results indicated, the \% removal decreased with an increase in drug concentration. Nifedipine was removed quickly; it was removed just after $10 \mathrm{~min}$ using $5 \mathrm{mg} / \mathrm{L}$ concentration whilst it was eliminated after $40 \mathrm{~min}$ with $10 \mathrm{mg} / \mathrm{L}$ of initial concentration. Only caffeine, prazosin, enalapril, and carbamazepine were still resistant using $5 \mathrm{mg} / \mathrm{L}$, they were not completely removed after $40 \mathrm{~min}$.

\section{2. Effect of Sodium Chloride Dose}

Hypochlorite ions $\mathrm{ClO}^{-}$are produced due to the presence of chloride ions $\left(\mathrm{Cl}^{-}\right)$/free chlorine $\left(\mathrm{Cl}_{2}\right)$ in the electrolysis system and are regarded as the main oxidizing agent of the electrochemical oxidation process. The $\mathrm{ClO}^{-}$ production is higher and dominant in the presence of $\mathrm{NaCl}$ salt compared to the absence of $\mathrm{NaCl}$.

The addition of $\mathrm{NaCl}$ as an electrolyte plays an important role to enhance the efficiency of electrochemical removal for the studied pharmaceuticals. Therefore, the continuous addition of sodium chloride was employed in this present study. Two different amounts of $\mathrm{NaCl}, 0.1$ and $0.2 \mathrm{~g}$ per $100 \mathrm{~mL}$, were investigated within $50 \mathrm{~min}$. The applied voltage was kept at $5 \mathrm{~V}$ and the initial concentration was fixed at $5 \mathrm{mg} / \mathrm{L}$. It was observed from Figure $3 \mathrm{~b}$, the initial\% removal increased with increasing of $\mathrm{NaCl}$ amount and it was reached as the highest when $\mathrm{NaCl}$ was $0.2 \mathrm{~g} / 100 \mathrm{~mL}$. It was observed that nifedipine was completely degraded after $10 \mathrm{~min}$ of electrolysis in the presence of $2 \mathrm{~g} / \mathrm{L} \mathrm{NaCl}$, in which levonorgestrel and simvastatin were eliminated in the same way at the end of process. However, most of the pharmaceuticals achieved more than $50 \%$ removal after $30 \mathrm{~min}$. On the other hand, all compounds were not completely removed in the presence of 1 $\mathrm{g} / \mathrm{L} \mathrm{NaCl}$. The reason was attributed to the role of $\mathrm{Cl}^{-}$in the electrochemical oxidation process to generate $\mathrm{ClO}^{-}$, which was not sufficient to make the full degradation for the studied pharmaceuticals at $1 \mathrm{~g} / \mathrm{L} \mathrm{NaCl}$.

It was observed from the LC-TOF/MS profile that most of the pharmaceuticals were eliminated in the presence of $2 \mathrm{~g} / \mathrm{L} \mathrm{NaCl}$ compared to $1 \mathrm{~g} / \mathrm{L} \mathrm{NaCl}$ under the same conditions of $5 \mathrm{~V}$ and 50 min treatment time (Figure S1). The indirect electrochemical oxidation mechanism for the generation of active chlorine $\left(\mathrm{Cl}_{2}, \mathrm{HOCl}\right.$, and $\left.\mathrm{ClO}^{-}\right)$was presented in the Introduction section.

\section{3. Effect of Applied Voltage}

Anodic oxidation of pharmaceuticals generates intermediates by the electrochemical oxidation -reactions of the chloride ions in the solution as described by the equations (1-3) in the Introduction section. However, the solution contained chloride ions due to the aqueous dissociation of the $\mathrm{NaCl}$ into $\mathrm{Na}^{+}$and $\mathrm{Cl}^{-}$. Thus, the oxidation under these conditions, usually called electrooxidation with active chlorine, is based on the direct oxidation of $\mathrm{Cl}^{-}$ at the anode to yield soluble chlorine, which diffuses away from the anode to be rapidly hydrolysed and transformed into hypochlorous acid ( $\mathrm{HOCl}$ ) and the chloride ion. Hypochlorous acid is then in equilibrium with hypochlorite ion at $\mathrm{p} K_{\mathrm{a}}=7.55$. From the literature, it was found that the dominant species are as follows: $\mathrm{Cl}_{2}$ until $\mathrm{pH}$ near $3, \mathrm{HClO}$ in the $\mathrm{pH}$ range $3-8$, and $\mathrm{ClO}^{-}$at $\mathrm{pH}>8$. It has been reported that the oxidation treatment with active chlorine species is faster in acid than in alkaline media because of the higher standard potential of $\mathrm{Cl}_{2}\left(E^{0}=1.36 \mathrm{~V}\right)$ and $\mathrm{HClO}\left(E^{0}=1.49 \mathrm{~V}\right)$ compared to $\mathrm{ClO}^{-}\left(E^{0}=0.89 \mathrm{~V}\right){ }^{29}$

In Figure 3c, the\% removal increased when applied voltage was raised from 3 to $12 \mathrm{~V}$, indicating an enhancement of the oxidation rate. This was due to the higher electroregeneration of $\mathrm{ClO}^{-}$ions from chlorine as discussed before. It was observed that at $12 \mathrm{~V}$ that the $\%$ removal bar curves reveal a quicker decay. Only prazosin, enalapril and carbamazepine were present after $10 \mathrm{~min}$. However, after 50 min all compounds were completely removed. In the case of $5 \mathrm{~V}$, the\% removal was between 81 and $96 \%$ for caffeine, prazosin, enalapril, and carbamazepine. Nifedipine, levonorgestrel and simvastatin were completely removed at the end of the electrochemical treatment process. The trend was different for $3 \mathrm{~V}$, it was shown that all pharmaceuticals were not removed after 50 
$\min$. The reason may be attributed to the fact that the concentration of the formed $\mathrm{ClO}^{-}$was low. LC-TOF/MS profile for the removal of pharmaceuticals has been observed and showed that most of the pharmaceuticals were eliminated following the increasing of applied voltage as presented in Figure S2.
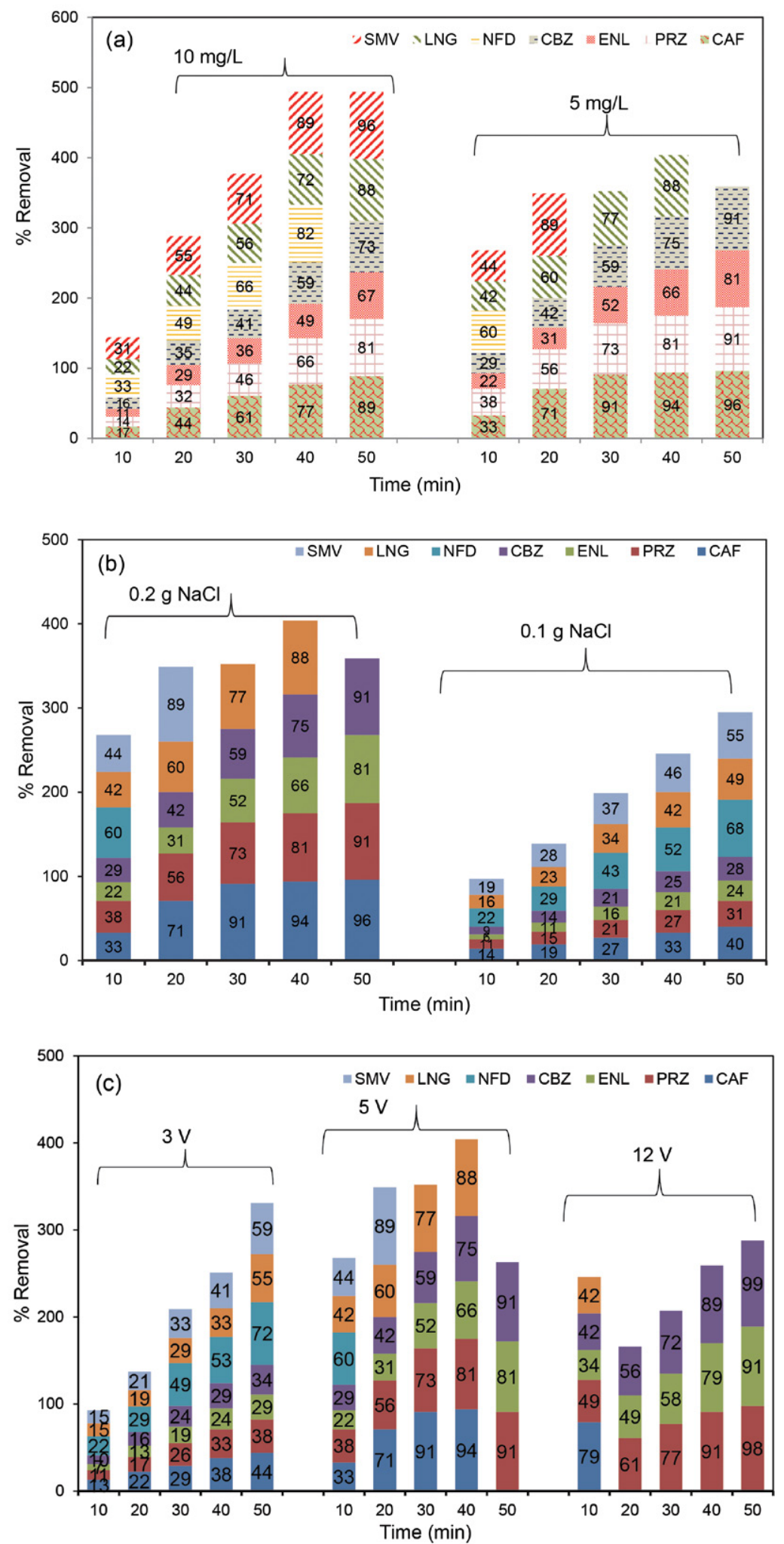

Figure 3.\% Removal for all studied pharmaceuticals: (a) effect of initial concentration at $5 \mathrm{~V}$ and $2 \mathrm{~g} / \mathrm{L} \mathrm{NaCl}$, (b) effect of $\mathrm{NaCl}$ amount at $5 \mathrm{~V}$ and 5 $\mathrm{mg} / \mathrm{L}$ and (c) effect of applied voltage at $5 \mathrm{mg} / \mathrm{L}$ and $2 \mathrm{~g} / \mathrm{L} \mathrm{NaCl}$. 
During the electrochemical process, energy consumption was considered for four pharmaceuticals only (caffeine, prazosin, enalapril, and carbamazepine) as a model of pharmaceuticals. It was calculated using equation $6:^{30}$

$$
\mathrm{EC}=\left[\frac{V I \Delta t}{\Delta m}\right]
$$

where EC (kWh/g compound) is energy consumption for the process; $V$ (volt) is the applied voltage, $I$ (ampere) is the current, $t$ (hours) is the electrolysis time and $\Delta m$ (gram) is the amount of reduced compound.

From Figure 4, energy consumption exhibited the highest value at $12 \mathrm{~V}$ compared to 5 and $3 \mathrm{~V}$. Energy consumption was almost similar at 5 and $3 \mathrm{~V}$, however, it was very low compared to $12 \mathrm{~V}$. On the other hand,\% removal was higher at $5 \mathrm{~V}$ compared to $3 \mathrm{~V}$ as shown in Figure 3c. Consequently, $5 \mathrm{~V}$ was the best choice for further experiments due to its low energy consumption and good compromise\% removal for most of the compounds.

\section{4. Identification of the By-products}

After electrochemical degradation of the parent compounds, some new by-products were formed. Howev- er, analysis of the by-products requires some further experiments to ensure their detection in trace amounts. LCTOF/MS is an instrument used for this purpose. In this study, only chlorinated by-products were analysed and reported because chlorinated by-products are more common harmful compounds than other non-chlorinated by-products. Furthermore, chlorine has two isotopes ${ }^{35} \mathrm{Cl}$ and ${ }^{37} \mathrm{Cl}$ with a big difference in abundance between them so they show clear separation and are very readily seen in mass spectrometry spectra and chromatograms.

Four pharmaceutical compounds, simvastatin, prazosin, carbamazepine, and caffeine were analysed and discussed in terms of the generation of their by-products using LC-TOF/MS. Other pharmaceuticals have not presented chlorinated by-products. It was observed that chlorinated by-products could be formed due to the presence of chlorine in the solution then oxidation reaction will occur via hypochlorite ion $\mathrm{ClO}^{-} .{ }^{31}$ During the electrochemical oxidation, several compounds were produced in the solution, however, it was very difficult to identify them because the electrochemical process was non-selective. Hence, it is very important to use an accurate instrument LC-TOF/MS for this purpose. The formation of the chlorinated by-products suggested the attack of $\mathrm{ClO}^{-}$generated by electrochemical oxidation of $\mathrm{Cl}^{-}$as has been discussed

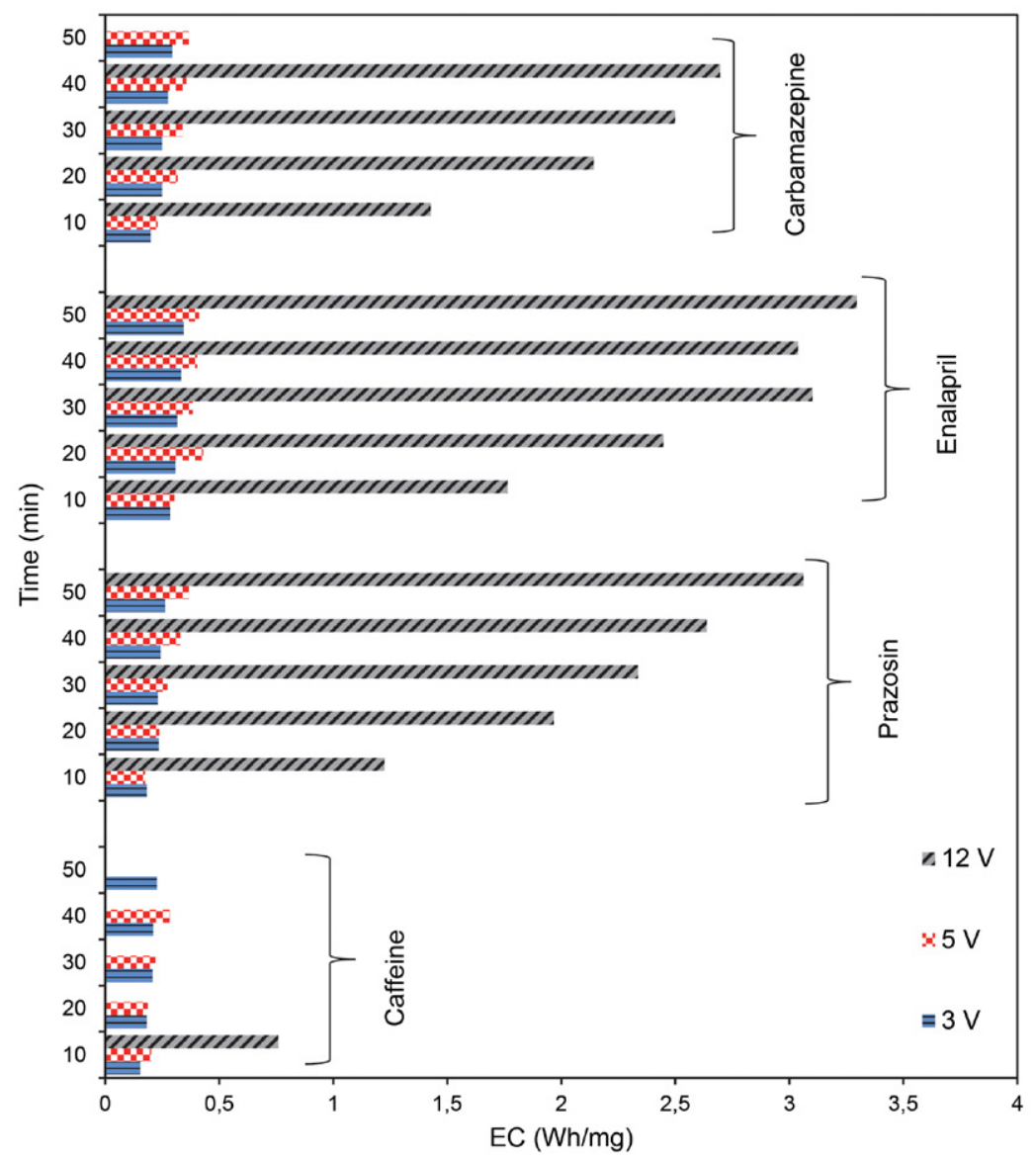

Figure 4. Effect of applied voltage on the energy consumption at $5 \mathrm{mg} / \mathrm{L}$ and $2 \mathrm{~g} / \mathrm{L} \mathrm{NaCl}$. 
previously. ${ }^{32,33}$ However, two main products, $\mathrm{C}_{11} \mathrm{H}_{13} \mathrm{C}$ $\mathrm{l}_{3} \mathrm{O}_{5}$, and $\mathrm{C}_{10} \mathrm{H}_{12} \mathrm{Cl}_{4} \mathrm{O}_{3}$, were produced during the electrochemical oxidation of simvastatin as presented in Table 3.

Figure $5 \mathrm{a}$ shows the mass spectrum of simvastatin by-product $(\mathrm{m} / z$ 327.9688). The most striking aspects of these spectra were the clusters of intense peaks that were separated by $m / z 2$ units. However, the identification of the ion cluster $m / z 327.9 / 329.9 / 331.9 / 333.9$ is explained here.
After careful examination of the ion cluster, it is evident that it should be a chlorine-containing by-product. The four peaks at $m / z 327.9 / 329.9 / 331.9 / 333.9$ display an ion cluster with an isotopic peak abundance ratio of 100\%:95.6\%:30.5\%:3.2\%, indicating that this by-product contains three chlorine atoms.

On the other hand, the by-product $\mathrm{C}_{10} \mathrm{H}_{12} \mathrm{Cl}_{4} \mathrm{O}_{3}$ $(\mathrm{m} / z$ 361.9310) has four chlorine atoms. However, the mass spectrum profile for this product shows five main

Table 3. Accurate mass measurement for selected pharmaceuticals and their by-products under the conditions $5 \mathrm{~V}$ and $5 \mathrm{~g} / \mathrm{L} \mathrm{NaCl}$.

\begin{tabular}{|c|c|c|c|c|}
\hline Parent compound/ & $\begin{array}{l}\text { Elemental composition } \\
\text { /by-product }\end{array}$ & Ionization mode & Molecular structure & $\begin{array}{l}\text { Mass to charge } \\
\text { ratio }(m / z)\end{array}$ \\
\hline \multirow[t]{2}{*}{ Simvastatin } & $\mathrm{C}_{11} \mathrm{H}_{13} \mathrm{O}_{5} \mathrm{Cl}_{3}$ & Negative & & 327.9688 \\
\hline & $\mathrm{C}_{11} \mathrm{H}_{12} \mathrm{O}_{5} \mathrm{Cl}_{4}$ & Negative & & 361.9310 \\
\hline \multirow[t]{2}{*}{ Prazosin } & $\mathrm{C}_{13} \mathrm{H}_{12} \mathrm{~N}_{5} \mathrm{O}_{3} \mathrm{Cl}_{3}$ & Negative & & 389.9985 \\
\hline & $\mathrm{C}_{10} \mathrm{H}_{11} \mathrm{~N}_{2} \mathrm{O}_{2} \mathrm{Cl}_{4}$ & Negative & & 329.9486 \\
\hline Carbamazepine & $\mathrm{C}_{15} \mathrm{H}_{11} \mathrm{~N}_{2} \mathrm{O}_{2} \mathrm{Cl}$ & Positive & & 309.0248 \\
\hline Caffeine & $\mathrm{C}_{8} \mathrm{H}_{9} \mathrm{~N}_{4} \mathrm{O}_{2} \mathrm{Cl}$ & Positive & & 229.0475 \\
\hline
\end{tabular}



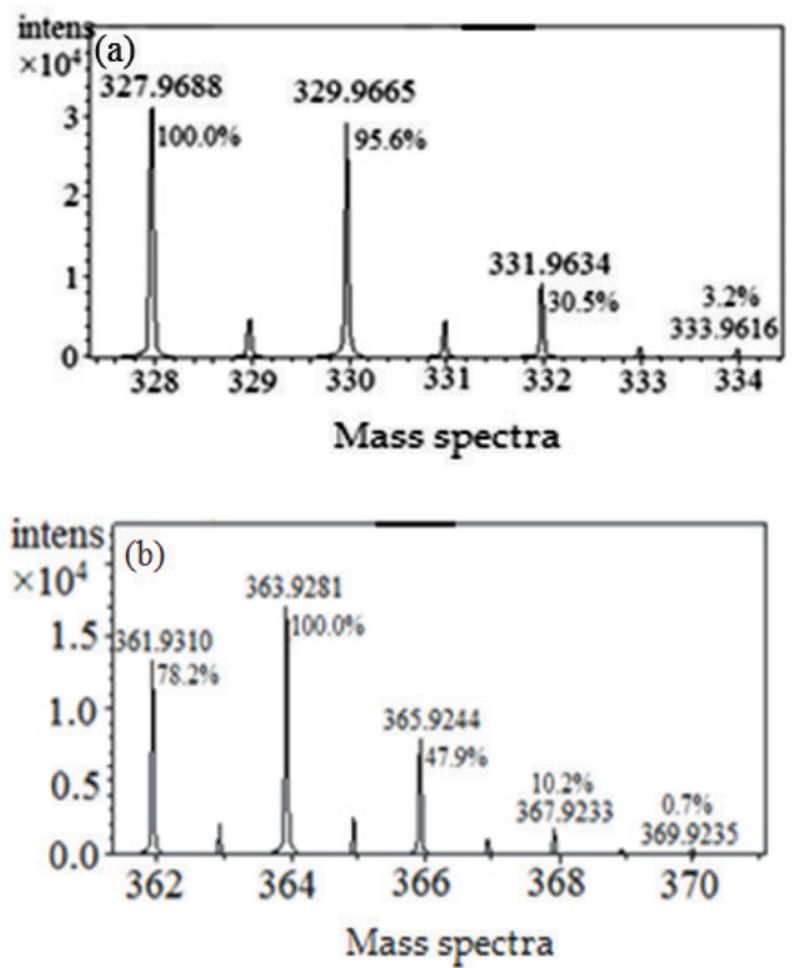

Figure 5. Mass spectra profile using LC-TOF/MS for simvastatin chlorinated by-products (a): three chlorine atoms and (b) four chlorine atoms.

peaks at $m / z 361.9,363.9,365.9,367.9$, and 369.9 , as presented in Figure 5b. The probability of appearance of these five isotopic mass peaks is arranged as $78.2 \%: 100 \%: 47.9 \%$ : 10.2\%:0.7\%, respectively.

Table 3 shows an illustration of the formation of two products: $\mathrm{C}_{13} \mathrm{H}_{12} \mathrm{Cl}_{3} \mathrm{~N}_{5} \mathrm{O}_{3}$ and $\mathrm{C}_{10} \mathrm{H}_{11} \mathrm{Cl}_{4} \mathrm{~N}_{2} \mathrm{O}_{2}$. After careful examination of the ion cluster for $\mathrm{C}_{13} \mathrm{H}_{12} \mathrm{Cl}_{3} \mathrm{~N}_{5} \mathrm{O}_{3}$, it was evident that it should be a chlorine-containing by-product. The inset panel shows that the peak at $\mathrm{m} / \mathrm{z}$ $390 / 392 / 394 / 396$ displays an ion cluster with an isotopic peak abundance ratio of 100\%:100\%:33\%:4\%, indicating that this by-product contains three chlorine atoms. On the other hand, product $\mathrm{C}_{10} \mathrm{H}_{11} \mathrm{Cl}_{4} \mathrm{~N}_{2} \mathrm{O}_{2}, \mathrm{~m} / z$ 329.9486, has four chlorine atoms identified as the five main peaks at $\mathrm{m} / \mathrm{z}$ $329.9,331.9,333.9,335.9$, and 337.9 , and arranged as 75\%:100\%:50\%:11\%:1\%, respectively.

In case of carbamazepine and caffeine, their by-products with one chlorine atom were identified as $\mathrm{C}_{15} \mathrm{H}_{11} \mathrm{~N}_{2} \mathrm{O}$ ${ }_{2} \mathrm{Cl}$ and $\mathrm{C}_{8} \mathrm{H}_{9} \mathrm{~N}_{4} \mathrm{O}_{2} \mathrm{Cl}$, respectively, as shown in Table 3 . The intense peaks for both compounds are presented in similar arrangement for the intense base isotope peaks as 100\%:30\%.

\section{Conclusions}

In this study, different pharmaceuticals were treated using the electrochemical oxidation process. The electrochemical process showed that caffeine, prazosin, simvas- tatin, and levonorgestrel were eliminated within 30-50 min using graphite-PVC composite electrode at 5 and 12 $\mathrm{V}$. This present study was reported for the first time explaining the treatment of the mixture of pharmaceuticals in a single reactor. The electrochemical oxidation process was investigated in the presence of $\mathrm{NaCl}$ as a supporting electrolyte under different applied voltages. Energy consumption was evaluated for four pharmaceuticals under different conditions. It ranged between 0.154 and 0.345 $\mathrm{Wh} / \mathrm{mg}$ at $3 \mathrm{~V}, 0.175$ and $0.430 \mathrm{Wh} / \mathrm{mg}$ at $5 \mathrm{~V}$, and 0.760 and $3.300 \mathrm{Wh} / \mathrm{mg}$ at $12 \mathrm{~V}$. The formation of chlorinated by-products was identified and elucidated strongly using LC-TOF/MS.

Conflicts of Interest: The authors declare no conflict of interest.

\section{Acknowledgments}

The authors thank Mr. Alefee who is the person-incharge of LC-TOF/MS. The authors also would like to thank University of Babylon to make agreement with other universities for providing the facilities to conduct this study. The authors would like to thank Al-Mustaqbal University College for funding this research.

\section{References}

1. Drugbank database. https://go.drugbank.com (accessed: 28 February 2020)

2. L. Vergeynst, A. Haeck, P. De Wispelaere, H. Van Langenhove, K. Demeestere, Chemosphere, 2015, 119, S2-S8.

DOI:10.1016/j.chemosphere.2014.03.069

3. I. Ferrer, E. M. Thurman, J. Chromatogr. A, 2012, 1259, 148157. DOI:10.1016/j.chroma.2012.03.059

4. N. K. Khalid, D. Devadasan, U. K. Aravind, C. T. Aravindakumar, Environ. Monit. Assess. 2018, 190, 1-12.

DOI:10.1007/s10661-018-6745-9

5. R. W. Becker, M. Ibáñez, E. C. Lumbaque, M. L. Wilde, T. F. da Rosa, F. Hernández, C. Sirtori, Sci. Total Environ. 2020, 699, 134-218. DOI:10.1016/j.scitotenv.2019.134218

6. F. F. Al-Qaim, M. P. Abdullah, M. R. Othman, J. Latip, Z. Zakaria, J. Chromatogr. A, 2014, 1345, 139-153.

DOI:10.1016/j.chroma.2014.04.025

7. F. F. Al-Qaim, M. P. Abdullah, M. R. Othman, J. Latip, W. Afiq, J. Brazil. Chem. Soc. 2014, 25, 271-281. DOI:10.5935/0103-5053.20130294

8. F. F. Al-Qaim, M. P. Abdullah, M. R. Othman, Z. H. Mussa, Z. Zakaria, J. Latip, W. M. Afiq, J. Brazil. Chem. Soc. 2015, 26, 1124-1135. DOI:10.5935/0103-5053.20150075

9. F. F. Al-Qaim, Z. Mussa, A. Yuzir, N. Tahrim, N. Hashim, S. Azman, Water, 2018, 10, 916. DOI:10.3390/w10070916

10. F. F. Al-Qaim, Z. H. Mussa, A. Yuzir, Anal.Bioanal.Chem.2018, 410, 4829-4846. DOI:10.1007/s00216-018-1120-9 
11. C. L. Amorim, I. S. Moreira, A. R. Ribeiro, L. H. Santos, C. Delerue-Matos, M. E. Tiritan, P. M. Castro, Int. Biodeter. Biodegr. 2016, 115, 277-285.

DOI:10.1016/j.ibiod.2016.09.009

12. M. Klavarioti, D. Mantzavinos, D. Kassinos, Environ. Int.2009, 35, 402-417. DOI:10.1016/j.envint.2008.07.009

13. T. Jerič, R. J. Bisselink, W. Van Tongeren, A. M. Le Marechal, Acta Chim. Slov. 2013, 60, 666-672. https://journals.matheo. si/index.php/ACSi/article/view/104

14. F. F. Al-Qaim, Z. H. Mussa, M. R. Othman, M. P. Abdullah, J.Hazard.Mater. 2015, 300, 387-397.

DOI:10.1016/j.jhazmat.2015.07.007

15. J. B. Parsa, M. Abbasi, Acta Chim. Slov. 2007, 54, 792.

16. Q. Ren, C. Kong, Z. Chen, J. Zhou, W. Li, D. Li, Y. Lu, Microchem. J. 2021, 164, 106059.

DOI:10.1016/j.microc.2021.106059

17. I. W. Mwangi, E. M. Kinyua, R. Nthumbi, R. N. Wanjau, S. Swaleh, J. C. Ngila, Heliyon, 2021, 7, e06671.

DOI:10.1016/j.heliyon.2021.e06671

18. G. Lourinho, D. M. F. Santos, P. S. D. Brito, J. Environ. Chem. Eng. 2021, 9, 104712. DOI:10.1016/j.jece.2020.104712

19. H. Li, X. Kuang, C. Qiu, X. Shen, B. Zhang, H. Li, Water Sci. Technol. 2020, 82, 773-786. DOI:10.2166/wst.2020.387

20. Z. H. Mussa, F. F. Al-Qaim, M. R. Othman, M. P. Abdullah, J. Latip, Z. Zakria, J. Taiwan Inst.Chem. E.2017, 72, 37-44. DOI:10.1016/j.jtice.2016.12.031

21. Z. H. Mussa, F. F. Al-Qaim, M. R. Othman, M. P. Abdullah, J. Environ. Chem. Eng., 2016, 4, 3338-3347.

DOI:10.1016/j.jece.2016.07.006
22. N. Nordin, M. A. F. Pisal, N. I. H. Razman, N. F. Jaafar, Acta Chim. Slov. 2019, 66, 284-293. DOI:10.17344/acsi.2018.4705

23. N. Nordin, S. F. M. Amir, M. R. Yusop, M. R. Othman, Acta Chim. Slov. 2015, 62, 642-651. DOI:10.17344/acsi.2014.1264

24. Z. H. Mussa, M. R. Othman, M. P. Abdullah, J. Brazil. Chem. Soc. 2015, 26, 939-948. DOI:10.5935/0103-5053.20150055

25. Malaysian Statistics on Medicine, Ministry of Health Malaysia, Kuala Lumpur. 2014. http://apps.who.int/medicinedocs/documents/s17580en/s17580en.pdf/ (accessed: 20 February 2020).

26. World Health Organization (WHO), collaborating center for drug statistics methodology, https://www.whocc.no/ atc_ddd_index/?code $=$ C07AB02\&showdescription $=y e s /(a c-$ cessed: 28 February 2020).

27. Z. Mussa, F. Al-Qaim, A. Yuzir, H. Hara, S. Azman, S. Chelliapan, Catalysts, 2018, 8, 540. DOI:10.3390/catal8110540

28. F. F. Al-Qaim, Z. H. Mussa, A. Yuzir, J. Latip, M. R. Othman, J. Environ. Sci.2018, 74, 134-146.

DOI:10.1016/j.jes.2018.02.019

29. I. Sirés, E. Brillas, Environ.Int.2012, 40, 212-229. DOI:10.1016/j.envint.2011.07.012

30. J. B. Parsa, M. Rezaei, A. R. Soleymani, J. Hazard. Mater. 2009, 168, 997-1003. DOI:10.1016/j.jhazmat.2009.02.134

31. M. Soufan, M. Deborde, A. Delmont, B. Legube, Water Res. 2013, 47, 5076-5087. DOI:10.1016/j.watres.2013.05.047

32. A. Sánchez-Carretero, C. Sáez, P. Cañizares, M. A. Rodrigo, Chem. Eng. J. 2011, 166, 710-714.

DOI:10.1016/j.cej.2010.11.037

33. M. J. Martín de Vidales, C. Sáez, P. Cañizares, M. A. Rodrigo, J. Chem. Technol. Biotechnol. 2012, 87, 225-231. DOI:10.1002/jctb.2701

\section{Povzetek}

V tej študiji poročamo o elektrokemijski obdelavi različnih terapevtskih skupin farmacevtikov (kofein, prazosin, enalapril, karbamazepin, nifedipin, levonorgestrel in simvastatin) v mešanici. Med elektrokemijskim procesom smo raziskovali uporabo grafitne-PVC anode pri različnih potencialih $(3,5$ in $12 \mathrm{~V})$, različnih začetnih koncentracijah preučevanih farmacevtikov v vodni raztopini ( 5 in $10 \mathrm{mg} / \mathrm{L}$ ) ter pri različnih koncentracijah natrijevega klorida ( 1 in 2 g/L). Delež odstranitve farmacevtikov se je povečeval $\mathrm{z}$ uporabljenim potencialom in je bil nad $98 \%$ po 50 min elektrolize pri $5 \mathrm{~V}$. Poraba energije je bila med 0,760 in 3,300 Wh/mg pri $12 \mathrm{~V}$, kar je bila najvišja vrednost v primerjavi s 3 ali $5 \mathrm{~V}$. Nastanek kloriranih stranskih produktov smo spremljali pri štirih izbranih farmacevtikih: simvastatin $\left(\mathrm{C}_{11} \mathrm{H}_{13} \mathrm{Cl}_{3} \mathrm{O}_{5}\right.$ in $\mathrm{C}_{10} \mathrm{H}_{12} \mathrm{C}$ $\left.\mathrm{l}_{4} \mathrm{O}_{3}\right)$, prazosin $\left(\mathrm{C}_{13} \mathrm{H}_{12} \mathrm{Cl}_{3} \mathrm{~N}_{5} \mathrm{O}_{3}\right.$ in $\left.\mathrm{C}_{10} \mathrm{H}_{11} \mathrm{Cl}_{4} \mathrm{~N}_{2} \mathrm{O}_{2}\right)$, karbamazepin in kofein $\left(\mathrm{C}_{15} \mathrm{H}_{11} \mathrm{~N}_{2} \mathrm{O}_{2} \mathrm{Cl}_{\text {in }} \mathrm{C}_{8} \mathrm{H}_{9} \mathrm{~N}_{4} \mathrm{O}_{2} \mathrm{Cl}\right)$, kjer smo strukturo produktov ugotovili z uporabo tekočinske kromatografije z masno spektrometrijo na čas preleta (LC-TOF/MS).

Except when otherwise noted, articles in this journal are published under the terms and conditions of the Creative Commons Attribution 4.0 International License 